\title{
A typology of corporate and family dairy farms in eastern Goiás, Brazil
}

\section{Bruna Sesco de Mendonça ${ }^{1^{*}}$ (i) Ferenc Istvan Bánkuti ${ }^{1,2}$ (i) Magali Soares dos Santos Pozza ${ }^{2}$ (D) Henrique Leal Perez $^{3}$ (D) Tiago Teixeira da Silva Siqueira ${ }^{4}$ (iD)}

${ }^{1}$ Programa de Pós-graduação em Medicina Veterinária, Universidade Estadual de Maringá (UEM), 87020-900, Maringá, PR, Brasil. E-mail: b sesco@hotmail.com. ${ }^{*}$ Corresponding author.

${ }^{2}$ Programa de Pós-graduação em Zootecnia, Universidade Estadual de Maringá (UEM), Maringá, PR, Brasil.

${ }^{3}$ Departamento de Zootecnia, Universidade Estadual de Maringá, (UEM), Maringá, PR, Brasil.

${ }^{4}$ École d'Ingénieurs de Purpan (EIP), Toulousse, France.

ABSTRACT: This study aimed to identify a typology of corporate and family dairy farms in eastern Goiás, Brazil. A semi-structured questionnaire was administered to 170 farm operators in the municipalities of Cristalina, Luziania, and Silvânia. Dairy farms were categorized into two groups, corporate and family farms. Data were analyzed by exploratory factor analysis using principal component analysis extraction. Four factors were identified: Milking management (F1), Production scale (F2), Productivity (F3), and Sociodemographic characteristics (F4). Corporate and family farms were then compared in terms of factor scores. Corporate farms scored higher on F1 and F2 and were characterized by larger production scale, greater adoption of milking management and hygiene practices; and consequently, greater alignment with institutional and market demands. These results indicated that corporate dairy farms in eastern Goiás have higher sustainability and are more likely to remain in business than family dairy farms.

Key words: factor analysis, scale of production, social factor, milking management, productivity.

Tipologia de sistemas produtivos leiteiros familiares e patronais na região leste de Goiás

RESUMO: Buscou-se analisar a tipologia de sistemas produtivos leiteiros familiares e patronais, localizados na região leste do estado de Goiás. Foram aplicados formulários semiestruturados em 170 sistemas produtivos leiteiros nas cidades de Cristalina, Luziânia e Silvânia. Os sistemas leiteiros foram segregados em dois grupos G1: produtores familiares e G2 produtores patronais. Para as demais variáveis foi aplicada a técnica de Análise Fatorial Exploratória - AFE com método de extração de Componentes Principais - ACP. Quatro Fatores foram obtidos: F1- manejo de ordenha, F2 - escala de produção, F3 - produtividade e, F4 - social. Os grupos G1 e G2 foram comparados frente aos Fatores. Produtores de leite patronais (G2) apresentaram maiores resultados para F1 e F2 quando comparados com produtores de leite familiares (G1). Desta forma, entre os sistemas produtivos leiteiros analisados, aqueles classificados como patronais (G2) apresentaram maior escala de produção de leite, maior frequência na adoção práticas de manejo e higiene de ordenha e portanto, estão mais adequados as demandas institucionais e de mercado atuais.

Palavras-chave: análise fatorial, escala de produção, fator social, manejo de ordenha, produtividade.

\section{INTRODUCTION}

Brazil is the third-largest milk producer in the world, with 33.8 billion liters of milk produced in 2018 (FAO, 2018). Although, milk is produced in all Brazilian states, the activity is concentrated in Minas Gerais, Rio Grande do Sul, Paraná, and Goiás (IBGE, 2017a). Family farms are the predominant form of dairy production systems, accounting for $60 \%$ of the national milk production (SEAD, 2018c). In general, family farms are small scale, and most of their production is used for self-consumption (BÁNKUTI et al., 2018; MEDINA et al., 2015; BUAINAIN et al., 2007). Because of these characteristics, family dairy farms seem to be less competitive and,;consequently, more economically vulnerable than corporate farms (BÁNKUTI et al., 2018). This assumption becomes even more evident when considering the institutional and market changes that occurred in the 1990s in the Brazilian agroindustrial system, including 
market deregulation, trade opening, and reduction of import tariffs for milk and milk derivatives (BONDENMÜLLER FILHO et al., 2010; MARION FILHO \& REICHERT, 2014).

A few years later, the Brazilian government established new standards for milk quality and transport through Normative Instructions nos. 51, 62, 31, 76, and 77 (MAPA, 2002, 2011, 2018a, 2018b, 2018c). To thrive in this new institutional and market environment, milk producers were compelled to acquire new production technologies and improve farm management (BUAINAIN et al., 2013). These changes led to an increase in productivity and milk quality for some farmers (BÁNKUTI, 2008). For many others; however, such changes resulted in activity abandonment or decreased competitiveness. As a consequence, dairy production systems in Brazil have become even more heterogeneous (BUAINAIN et al., 2013).

The high heterogeneity of Brazilian dairy production systems hinders the development of general public or private interventions. Typological studies arise as important tools to provide information for decision- and policy-makers (ANDERSEN et al., 2006; CHIKOWO et al., 2014; BONDENMÜLLER FILHO et al., 2010). This study aimed to determine the typology of family and corporate dairy farms in eastern Goiás, Brazil. Information on technical, productive, and socioeconomic characteristics of dairy farms can guide public and private interventions aimed to improve the competitiveness of dairy production systems.

\section{MATERIALS AND METHODS}

This typological investigation was conducted in the municipalities of Luziânia, Cristalina, and Silvânia, located in the eastern region of Goiás State, Brazil. In the last 10 years, milk production increased by $11.75 \%$ in Goiás and by $7.37,8.73$, and $29.91 \%$ in Luziânia, Cristalina, and Silvânia, respectively (IBGE, 2017b). During this period, Goiânia and Brasília, two capital cities located close to the study region, experienced a population growth of 12.56 and $14.23 \%$, respectively (IBGE, 2018). These data suggested that market demands for milk and dairy products have increased in the studied municipalities.

Data were collected in January 2018 through a semi-structured questionnaire administered in person to 170 farm operators (Table 2). The analyzed farms represent $4.25 \%$ of the total number of dairy farms in Goiás (IBGE, 2017a). Rural producers were selected from contact lists provided by local dairy industries, farmers' cooperatives, and technical assistance agencies. All contacted farmers who agreed to participate were included in the study.

The questionnaire gathered information on structural, technological, and production parameters as well as on the level of institutional adequacy of dairy farms (BRITO et al., 2015a, 2015b; LANGE et al., 2016; ZIMPEL et al., 2017a). Sociodemographic characteristics of farm operators were also analyzed (Table 1). The questionnaire was approved by the Human Research Ethics Committee (COPEP, protocol no. 2,396,173) of the State University of Maringá, Paraná, Brazil.

Descriptive statistics (minimum, maximum, mean, standard deviation, and frequency) were used for general characterization of the sample. Then, dairy farms were divided into two groups (corporate and family farms) based on criteria established by Law no. 11,326 (BRASIL, 2006). The factors that best described corporate and family dairy farms were determined using exploratory factor analysis (EFA) (BÁNKUTI et al., 2014; NEUMANN et al., 2016; YABE et al., 2015). The EFA is a multivariate statistical technique of interdependence that condenses a set of correlated variables into a smaller number of factors. Factors are composed of variables with high internal correlation and low correlation with variables from other factors. This variable reduction technique can be used to create indicators for decision-making (FÁVERO et al., 2009a). Several authors have used EFA to generate indicators for dairy production systems (BRITO et al., 2015a, 2015b; LANGE et al., 2016; NEUMANN et al., 2016; ZYMPEL et al., 2016).

Initially, 35 variables were selected for EFA. However, 19 of these variables failed to satisfy Bartlett's and Kaiser-Meyer-Olkin (KMO) criteria (FÁVERO et al., 2009). Thus, only 16 variables were used in EFA (Table 1). Retained variables were either ordinal categorical or numerical. Ordinal variables are qualitative but, as they can be ranked into a preferential order, are suitable for this type of analysis (FÁVERO et al., 2009).

Factors were extracted by principal component analysis using varimax rotation, Kaiser normalization, and Bartlett's test (BARROSO \& ARTES, 2003; FÁVERO et al., 2009). Variables with factor loadings lower than $|0.5|$ were discarded (HAIR et al., 2009). The number of retained factors was defined based on the Kaiser criterion (eigenvalues greater than 1.0) (FÁVERO et al., 2009; HAIR et al., 2009). 
Table 1 - Description of variables analyzed in the study.

\begin{tabular}{|c|c|c|c|c|}
\hline & Variable & Questionnaire item & Type & Statistical analysis \\
\hline V1 & Teat cleaning before milking & $\begin{array}{l}\text { Do you clean the cow's teats before attaching } \\
\text { the milking cups? }\end{array}$ & Ordinal & EFA \\
\hline $\mathrm{V} 2$ & Pre-dipping & $\begin{array}{l}\text { Do you perform pre-milking teat disinfection } \\
\text { (pre-dipping)? }\end{array}$ & Ordinal & EFA \\
\hline $\mathrm{V} 3$ & Post-dipping & $\begin{array}{l}\text { Do you perform post-milking teat disinfection } \\
\text { (post-dipping)? }\end{array}$ & Ordinal & EFA \\
\hline V4 & $\begin{array}{l}\text { Use of warm water for teat } \\
\text { cleaning }\end{array}$ & $\begin{array}{c}\text { Do you wash the cow's teats with warm } \\
\text { water? }\end{array}$ & Ordinal & EFA \\
\hline V5 & Milking equipment hygiene & $\begin{array}{c}\text { Do you clean the milking equipment after } \\
\text { use? }\end{array}$ & Ordinal & EFA \\
\hline V6 & Frequent mastitis testing & Do you frequently test cows for mastitis? & Ordinal & EFA \\
\hline V7 & Type of milking system & What type of milking system do you use? & Ordinal & EFA \\
\hline V8 & Number of dairy cows & How many dairy cows do you have? & Numerical & $\begin{array}{l}\text { EFA and descriptive } \\
\text { analysis }\end{array}$ \\
\hline V9 & Number of cows in milk & $\begin{array}{l}\text { How many cows in milk are there on the } \\
\text { farm? }\end{array}$ & Numerical & $\begin{array}{l}\text { EFA and descriptive } \\
\text { analysis }\end{array}$ \\
\hline V10 & $\begin{array}{l}\text { Daily milk production (L } \\
\text { day }^{-1} \text { ) }\end{array}$ & $\begin{array}{l}\text { How many liters of milk do you produce per } \\
\text { day? }\end{array}$ & Numerical & $\begin{array}{l}\text { EFA and descriptive } \\
\text { analysis }\end{array}$ \\
\hline V11 & Farm size (ha) & How many hectares comprise your farm? & Numerical & $\begin{array}{l}\text { EFA and descriptive } \\
\text { analysis }\end{array}$ \\
\hline V12 & Milk production area (ha) & $\begin{array}{l}\text { How many hectares do you use for milk } \\
\text { production? }\end{array}$ & Numerical & $\begin{array}{l}\text { EFA and descriptive } \\
\text { analysis }\end{array}$ \\
\hline V13 & $\begin{array}{l}\text { Milk production per area ( } \mathrm{L} \\
\left.\qquad \mathrm{ha}^{-1}\right)\end{array}$ & Calculated. & Numerical & $\begin{array}{l}\text { EFA and descriptive } \\
\text { analysis }\end{array}$ \\
\hline V14 & $\begin{array}{l}\text { Milk production per cow }(\mathrm{L} \\
\left.\operatorname{cow}^{-1} \text { day }^{-1}\right)\end{array}$ & Calculated. & Numerical & $\begin{array}{l}\text { EFA and descriptive } \\
\text { analysis }\end{array}$ \\
\hline V15 & Number of workers & How many people work on the farm? & Numerical & $\begin{array}{l}\text { EFA and descriptive } \\
\text { analysis }\end{array}$ \\
\hline V16 & Age of farm operator & How old are you? & Numerical & $\begin{array}{l}\text { EFA and descriptive } \\
\text { analysis }\end{array}$ \\
\hline V17 & $\begin{array}{l}\text { Level of education of farm } \\
\text { operator }\end{array}$ & $\begin{array}{l}\text { How many years of formal education have } \\
\text { you had? }\end{array}$ & Numerical & $\begin{array}{l}\text { EFA and descriptive } \\
\text { analysis }\end{array}$ \\
\hline V18 & Dairy farming experience & $\begin{array}{c}\text { How long have you worked in the dairy } \\
\text { business? }\end{array}$ & Numerical & $\begin{array}{l}\text { EFA and descriptive } \\
\text { analysis }\end{array}$ \\
\hline
\end{tabular}

EFA, exploratory factor analysis.

The EFA generates factor scores, which indicated the contribution of each dairy farm to the generated factors. The factor score is determined by multiplying factor coefficients by the original values of variables (FÁVERO et al., 2009). Scores were used as regression variables; in this procedure, factor loadings are adjusted from the initial correlations between variables, eliminating differences between units of measurement and normalizing variances. Factor scores of corporate and family dairy farms were compared using mean tests (FIELD, 2009). Data were tested for normality of distribution by the
Kolmogorov-Smirnov and Shapiro-Wilk tests and for homogeneity of variance by Levene's test. As the data were found to be non-normally distributed, the nonparametric Mann-Whitney $U$-test was used for comparison of means $(\mathrm{P}<0.05)($ FIELD, 2009).

\section{RESULTS AND DISCUSSION}

Dairy farms had an average size of 70.81 \pm 128.49 ha, of which $32.88 \pm 59.22$ ha were used for milk production. Farms produced $263.89 \pm 429.06$ $\mathrm{L} \mathrm{day}^{-1}$ and had $71.83 \pm 74.85$ cows, $31 \%$ of which 
were lactating cows. The mean milk production per cow was $10.23 \pm 4.58 \mathrm{~L} \mathrm{cow}^{-1}$ day $^{-1}$ (Table 2).

Farm operators had $45 \pm 15.22$ years of age, $17 \pm 13.05$ years of experience in dairy farming, and $6.71 \pm 4.37$ years of formal education. The average number of farm workers was $1.82 \pm 1.39$ (Table 2).

Of the 170 farms analyzed in this study, $48(28.23 \%)$ were corporate farms and $122(71.77 \%)$ were family farms, as classified according to criteria established by Law no. 11,326 (BRASIL, 2006). In the state of Goiás, more than $70 \%$ of food production systems are family run (IBGE, 2006).

Corporate and family farms did not differ $(P<0.05)$ in farm operator's age, level of education, or years of experience, indicating that farm operators of both groups had similar sociodemographic characteristics. Both types of farms had a similar number of farm workers (Table 3).

There were significant differences $(P<0.05)$ in farm size and milk production area between corporate and family farms (Table 3 ). Farm size is associated with the farm's capacity to produce feed and animals, influencing its dependency on external suppliers (FILHO et al., 2010; ZIMPEL et al., 2017b).

Daily milk production, number of cows and cows in milk, and milk production per cow differed $(P<0.05)$ between corporate and family farms. These parameters were higher in corporate farms (Table 3). Corporate farms produced $50.17 \%$ more milk per day than family farms. This high productivity was likely influenced by the high number of cows in milk (35.73 versus 17.10 in family farms). The recommendation is to have $83 \%$ of cows in milk for increased profits (EMBRAPA, 2007). Other factors, such as nutritional management, adoption of technologies, and investment in facilities, can also influence cow productivity and farm production scale.

EFA extracted 4 factors from the 16 structural, productive, and socioeconomic variables. Together, the factors explained $76.46 \%$ of the variance in the dataset (Table 4), meeting the criteria for EFA (FÁVERO et al., 2009a; HAIR et al., 2009). Bartlett's test was significant $(0.00)$ and the KMO value was 0.819 , indicating that the dataset was suitable for EFA (FÁVERO et al., 2009).

The first factor (F1) was denominated Milking management (Table 5). Milking management practices are strongly associated with milk quality (SURANINDYAH et al., 2015; de SILVA et al., 2016) and the price of milk in transactions with the dairy industry (BOZO et al., 2013).

The second factor (F2) was termed Production scale, because it was formed by the variables number of dairy cows, number of cows in milk, daily milk production, and farm size (Table 5). Farm area is an important variable, as it influences production scale and income, (ANDERSEN et al., 2006) and indicates the capacity to produce and stock feed as well as to expand facilities (MARCONDES et al., 2017; DEFANTE et al., 2019). On-farm feed production implies a lower dependency on external feed suppliers (BONDENMÜLLER FILHO \& BÁNKUTI, 2016). Daily milk production, number of lactating cows, and type of milking and cooling system are frequently investigated in typological studies of dairy farms, which have shown than daily milk production is positively correlated with number

Table 2 - Descriptive statistics of dairy farms in eastern Goiás, Brazil.

\begin{tabular}{|c|c|c|c|c|c|}
\hline Variable & $\mathrm{n}$ & Min & Max & Mean & SD \\
\hline Age of farm operator (years) & 170 & 14 & 86 & 45.76 & 15.22 \\
\hline Level of education of farm operator (years) & 170 & 0 & 21 & 6.71 & 4.38 \\
\hline Dairy farming experience (years) & 170 & 1 & 60 & 17.27 & 13.05 \\
\hline Farm size (ha) & 170 & 2 & 1003 & 70.81 & 128.49 \\
\hline Milk production area (ha) & 170 & 1.5 & 500 & 32.88 & 59.22 \\
\hline Number of workers & 170 & 1 & 15 & 1.83 & 1.39 \\
\hline Daily milk production $\left(\mathrm{L} \mathrm{day}^{-1}\right)$ & 170 & 25 & 4200 & 263.98 & 429.06 \\
\hline Number of cows in milk & 170 & 3 & 210 & 22.36 & 21.44 \\
\hline Number of dairy cows & 170 & 6 & 550 & 71.83 & 74.85 \\
\hline Milk production per cow $\left(\mathrm{L} \mathrm{cow}^{-1}\right.$ day $\left.^{-1}\right)$ & 170 & 3.33 & 30 & 10.23 & 4.58 \\
\hline Milk production per area $\left(\mathrm{L} \mathrm{ha}^{-1}\right)$ & 170 & 0.7 & 84 & 13.03 & 13.45 \\
\hline
\end{tabular}

SD, standard deviation. 
Table 3 - Comparison of corporate and family dairy farms in eastern Goiás, Brazil.

\begin{tabular}{|c|c|c|c|c|}
\hline Variable & Farm type & $\mathrm{n}$ & Mean & $\mathrm{SD}$ \\
\hline \multirow{2}{*}{ Age of farm operator (years) } & Corporate & 48 & $45.29^{\mathrm{a}}$ & 16.35 \\
\hline & Family-run & 122 & $45.94^{\mathrm{a}}$ & 14.83 \\
\hline \multirow{2}{*}{ Level of education of farm operator (years) } & Corporate & 48 & $7.33^{\mathrm{a}}$ & 4.94 \\
\hline & Family-run & 122 & $6.46^{\mathrm{a}}$ & 4.13 \\
\hline \multirow{2}{*}{ Dairy farming experience (years) } & Corporate & 48 & $17.69^{\mathrm{a}}$ & 14.91 \\
\hline & Family-run & 122 & $17.11^{\mathrm{a}}$ & 12.31 \\
\hline \multirow{2}{*}{ Farm size (ha) } & Corporate & 48 & $164.75^{\mathrm{a}}$ & 211.88 \\
\hline & Family-run & 122 & $33.85^{\mathrm{b}}$ & 27.32 \\
\hline \multirow{2}{*}{ Milk production area (ha) } & Corporate & 48 & $63.81^{\mathrm{a}}$ & 102.86 \\
\hline & Family-run & 122 & $20.71^{b}$ & 16.17 \\
\hline \multirow{2}{*}{ Number of workers } & Corporate & 48 & $1.85^{\mathrm{a}}$ & 0.90 \\
\hline & Family-run & 122 & $1.82^{\mathrm{a}}$ & 1.55 \\
\hline \multirow{2}{*}{ Daily milk production $\left(\mathrm{L} \mathrm{day}^{-1}\right)$} & Corporate & 48 & $505.63^{\mathrm{a}}$ & 691.88 \\
\hline & Family-run & 122 & $168.92^{b}$ & 197.27 \\
\hline \multirow{2}{*}{ Number of cows in milk } & Corporate & 48 & $35.75^{\mathrm{a}}$ & 32.69 \\
\hline & Family-run & 122 & $17.10^{\mathrm{b}}$ & 11.31 \\
\hline \multirow{2}{*}{ Number of dairy cows } & Corporate & 48 & $117.50^{\mathrm{a}}$ & 105.20 \\
\hline & Family-run & 122 & $53.87^{\mathrm{b}}$ & 48.73 \\
\hline \multirow{2}{*}{ Milk production per cow $\left(\mathrm{L} \mathrm{cow}^{-1}\right.$ day $\left.^{-1}\right)$} & Corporate & 48 & $12.04^{\mathrm{a}}$ & 5.48 \\
\hline & Family-run & 122 & $9.52^{\mathrm{b}}$ & 3.98 \\
\hline \multirow{2}{*}{ Milk production per area $\left(\mathrm{L} \mathrm{ha}^{-1}\right)$} & Corporate & 48 & $15.05^{\mathrm{a}}$ & 14.29 \\
\hline & Family-run & 122 & $12.24^{\mathrm{a}}$ & 13.09 \\
\hline
\end{tabular}

${ }^{\mathrm{a}, \mathrm{b}}$ Within variables, means followed by different letters differ significantly by the Mann-Whitney $U$-test $(\mathrm{P}<0.05)$.

of lactating cows and technological sophistication in milking and cooling (CHIKOWO et al., 2014; CORTEZ-ARRIOLA et al., 2015; DEFANTE et al., 2019; CASALI et al., 2020).

The third factor (F3), termed Productivity, was composed of the variables milk production per cow and per area (Table 5). Dairy farms with high productivity generally seek to optimize their production by adopting novel technologies and efficient production strategies, thereby obtaining greater financial returns (NEUMANN et al., 2016; VOGES et al., 2015; ZIMPEL et al., 2017).
The fourth factor (F4) was named Sociodemographic characteristics and comprised the variables age, level of education, and dairy farming experience of the farm operator (Table 5). Farm operator's age is associated with the adoption of new technologies and work techniques as well as the effort directed toward certain management factors (BYRNE et al., 2015; ASANTE et al., 2011). In general, older farm managers are resistant to technological and productive changes for fear of losing decisionmaking authority and capacity. Another factor that contributes to the resistance of older farm operators is

Table 4 - Total variance explained.

\begin{tabular}{|c|c|c|c|}
\hline Factor & 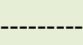 & ------------------' & --------------------- \\
\hline & Total & $\%$ of Variance & Cumulative \% \\
\hline 1 & 6.84 & 42.80 & 42.80 \\
\hline 2 & 2.45 & 15.31 & 58.12 \\
\hline 3 & 1.67 & 10.45 & 68.57 \\
\hline 4 & 1.26 & 7.88 & 76.46 \\
\hline
\end{tabular}

Ciência Rural, v.50, n.10, 2020. 
Table 5 - Factor loadings from exploratory factor analysis of sociodemographic, structural, and production characteristics of dairy farms in eastern Goiás, Brazil.

\begin{tabular}{|c|c|c|c|c|}
\hline \multirow[t]{2}{*}{ Variable } & \multicolumn{4}{|c|}{ 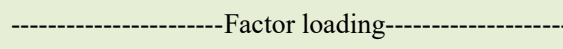 } \\
\hline & F1 & F2 & F3 & F4 \\
\hline Teat cleaning before milking & 0.928 & 0.088 & 0.124 & 0.068 \\
\hline Pre-dipping & 0.895 & 0.154 & 0.095 & 0.068 \\
\hline Post-dipping & 0.914 & 0.167 & 0.104 & 0.059 \\
\hline Use of warm water for teat cleaning & 0.887 & 0.183 & 0.115 & 0.035 \\
\hline Milking equipment hygiene & 0.834 & 0.078 & 0.124 & 0.172 \\
\hline Frequent mastitis testing & 0.792 & 0.069 & 0.094 & 0.112 \\
\hline Type of milking system & 0.674 & 0.449 & 0.266 & -0.005 \\
\hline Number of dairy cows & 0.149 & 0.878 & 0.141 & 0.009 \\
\hline Number of cows in milk & 0.223 & 0.865 & 0.232 & 0.053 \\
\hline Daily milk production $\left(\mathrm{L} \mathrm{day}^{-1}\right)$ & 0.231 & 0.818 & 0.413 & 0.034 \\
\hline Milk production area (ha) & 0.089 & 0.806 & -0.346 & -0.024 \\
\hline Milk production per area $\left(\mathrm{L} \mathrm{ha}^{-1}\right)$ & 0.157 & 0.043 & 0.883 & 0.129 \\
\hline Milk production per cow $\left(\mathrm{L} \mathrm{cow}^{-1}\right.$ day $\left.^{-1}\right)$ & 0.338 & 0.301 & 0.680 & 0.036 \\
\hline Age of farm operator & -0.062 & -0.048 & -0.147 & -0.849 \\
\hline Level of education of farm operator & 0.091 & 0.215 & -0.073 & 0.744 \\
\hline Dairy farming experience & -0.116 & 0.223 & -0.087 & -0.636 \\
\hline
\end{tabular}

F1, Milking management; F2, Production scale; F3, Productivity; F4, Sociodemographic characteristics.

the fear of retiring and losing the professional identity and respect earned throughout their lives (CONWAY et al., 2017; MARTÍNEZ-GARCÍA et al., 2013).

Young farm operators are more likely to adopt novel nutritional, management, and milking hygiene techniques because they believe the techniques produce positive results. In addition, such actions are performed more efficiently by younger farmers than by older farmers. Adoption of more efficient strategies generates positive and profitable results, enhancing production, hygiene, and management practices (ECKSTEIN et al., 2016; ZYMPEL et al., 2017).

Dairy farming experience and education level are other important factors influencing decisionmaking in dairy production systems (BUAINAIN et al., 2007; ECKSTEIN et al., 2016; ZIMPEL et al., 2016). Short time in the activity can affect the decisions and actions taken by the farm operator; however, more experienced farmers are more resistant to changes (CONWAY et al., 2017). Level of education is associated with workforce qualification and interpretation and understanding of production techniques. Education has a positive correlation with variables that determine dairy farming success, including income (MEDINA et al., 2015). Thus, more educated farm operators tend to adopt milking hygiene practices, as they understand that hygiene influences milk quality and, consequently, financial returns (ECKSTEIN et al., 2016; LANGE et al., 2016).

Corporate and family farms differed $(P<0.05)$ in F1 and F2 scores (Table 6). Corporate farms had a higher factor score $(0.465)$ on F1 than family farms $(-0.183)(P<0.05)$ (Table 6$)$, indicating that the former carried out milking management practices more frequently. Milking management practices include mastitis testing (e.g., strip cup test), teat disinfection, and equipment sanitation. By adopting these practices, corporate farms tend to produce higher-quality milk and, consequently, may obtain higher net returns per liter of milk. In addition, milking management practices can reduce the costs of disease treatment (ECKSTEIN et al., 2014, 2016).

The factor score on F2 was higher $(P<0.05)$ for corporate farms $(0.590)$ than for family farms $(-0.232)$ (Table 6). Family farms are in general small scale and have low product diversification, with higher dedication to the dairy activity (LANGE et al., 2016). Corporate farms are larger, allowing them to meet the market requirements for high volumes of milk. A low milk production area implies reduced animal capacity and inability to produce feed. Such characteristics, added to a low income, means that 
Table 6 - Comparison of factor scores of corporate and family dairy farms in eastern Goiás, Brazil.

\begin{tabular}{lcccc}
\hline Factor & Farm type & $\mathrm{n}$ & Mean & Standard deviation \\
\hline \multirow{2}{*}{ Milking management } & Corporate & 48 & $0.465^{\mathrm{a}}$ & 0.983 \\
& Family-run & 122 & $-0.183^{\mathrm{b}}$ & 0.950 \\
\multirow{2}{*}{ Production scale } & Corporate & 48 & $0.590^{\mathrm{a}}$ & 1.592 \\
& Family-run & 122 & $-0.232^{\mathrm{b}}$ & 0.469 \\
Productivity & Corporate & 48 & $0.067^{\mathrm{a}}$ & 1.280 \\
& Family-run & 122 & $-0.026^{\mathrm{a}}$ & 0.871 \\
Sociodemographic characteristics & Corporate & 48 & $-0.010^{\mathrm{a}}$ & 1.085 \\
& Family-run & 122 & $0.004^{\mathrm{a}}$ & 0.969 \\
\hline
\end{tabular}

${ }^{\mathrm{a}, \mathrm{b}}$ Within factors, means followed by different letters differ significantly by the Mann-Whitney $U$-test $(P<0.05)$.

farm operators are not able to purchase other inputs for milk production (QUDDUS, 2012). The financial resources of family farms are usually directed toward family expenses, with little investment in animals, farm size, inputs, and new equipment, influencing production scale (NEUMANN et al., 2016).

The differences in milking management and production scale between corporate and family farms might have been associated with the farm operator's decision-making. According to MARTÍNEZ-GARCÍA et al. (2013), decisionmaking is generally influenced by three main factors: lack of financial resources, resistance to the adoption of novel techniques, and third-party information. Farm size also affects decision-making, as it must be considered when determining the technological level adopted. Corporate farms are capable of investing in high-level technologies and can easily adapt to current institutional and market norms, contributing to profitability and reducing susceptibility (BÁNKUTI \& CALDAS, 2018). These characteristics explain why corporate farms had better results than family farms in the present study.

Dairy farms did not differ in F3 score (G1, -0.026 , and $\mathrm{G} 2,0.067 ; \mathrm{P}>0.05$ ) (Table 6). Thus; although, differences were reported between groups in production scale, the use of internal resources (animals and production area) was similar between corporate and family farms. In other words, regardless of the farm's capacity to produce animal feed, the mean milk production per cow was similar between groups. Family farmers' access to credit has boosted investment in feed and infrastructure. The small farm size (and consequently low feed production capacity) is compensated by supplementation with concentrate and silage. Investments in infrastructure, feed, and technologies can increase the productivity of family farms (CORTEZ-ARRIOLA et al., 2015; SOUZA \& BUAINAIN, 2013).

No differences in F4 scores were reported between family (0.010) and corporate (0.004) farms $(P<0.05$, Table 6$)$. In previous studies, the sociodemographic characteristics of farm operators did not influence the adoption of management tools or participation in farmers' cooperatives (BRITO et al., 2015b; SCHEBELESKI \& BÁNKUTI, 2016; ZIMPEL et al., 2016). Thus, other aspects must be considered to explain the differences between corporate and family farms.

Overall, our findings showed that family farms are smaller scale and adopt milking and hygiene practices less frequently than corporate farms. As a result, family farms have difficulty meeting market and institutional requirements for production volume and milk quality, which decreases their competitiveness compared to corporate farms.

\section{CONCLUSION}

This typological study showed that corporate dairy farms differ from family-run enterprises mainly in their greater adoption of production technologies, access to information, feed production capacity, and production area. These characteristics indicated that corporate dairy farms are better equipped to meet institutional and market demands for bulk milk, which implies reduced vulnerability and greater chances to stay in business in the medium and long term.

Public and private strategies are necessary to facilitate the adaptation of family dairy farms to the current institutional and market environment, particularly 
in terms of production scale. Increased participation in collective arrangements, such as efficiently managed dairy cooperatives, may help decrease the vulnerability of the analyzed family farms.

\section{ACKNOWLEDGEMENTS}

The authors thank the State University of Maringá, Paraná, Brazil, for supporting this research and the Araucária Foundation and the Brazilian Federal Agency for Support and was financed in part by the Coordenação de Aperfeiçoamento de Pessoal de Nível Superior (CAPES), Brasil - Finance code 001.' We also thank the farm operators who answered the questionnaire.

\section{DECLARATION OF CONFLICT OF INTERESTS}

The authors declare no conflict of interest. The founding sponsors had no role in the design of the study; in the collection, analyses, or interpretation of data; in the writing of the manuscript, and in the decision to publish the results.

\section{AUTHORS' CONTRIBUTIONS}

The authors contributed equally to the manuscript.

\section{REFERENCES}

ANDERSEN, E. et al. A multidimensional farming system typology, SEAMLESS Report No.12. SEAMLESS integrated project, EU 6th Framework Programme, 2006. v.12. Available from: $<$ http://www.seamless-ip.org/Reports/Report_12_PD4.4.2.pdf $>$. Accessed: Jan. 20, 2020.

ASANTE, B. O. et al. Determinants of small scale farmers' decision to join farmer based organizations in Ghana. African Journal of Agricultural Research, v.6, n.10, p.2273-2279, 2011. Available from: <https://academicjournals.org/journal/AJAR/ article-stat/7AD5DF139233>. Accessed: Jan. 21, 2020. doi: 10.5897/AJAR10.979.

BÁNKUTI, F. I. et al. Analysis of the potential competitiveness of dairy production in the micro region of Maringá . Informações Econômicas, v.44, n.1, p.12, 2014. Available from: <http:// www.iea.sp.gov.br/ftpiea/publicacoes/ie/2014/tec4-0214.pdf>. Accessed: Feb. 25, 2020.

BÁNKUTI, F. I.; CALDAS, M. M. Geographical milk redistribution in Paraná State, Brazil: Consequences of institutional and market changes. Journal of Rural Studies, v.64, n.August, p.63-72, 2018. Available from: <https://doi.org/10.1016/j.jrurstud.2018.10.004>. Accessed: Feb. 22, 2020. doi: 10.1016/j.jrurstud.2018.10.004.

BÁNKUTI, F. I. et al. Structural features, labor conditions and family succession in dairy production systems in Paraná State, Brazil. Cahiers Agriculture, v.27, n.45004, p.2-11, 2018. Available from: $<$ https://doi.org/10.1051/cagri/2018028>. Accessed: Mar. 25, 2020. doi: 10.1051/cagri/2018028.

BÁNKUTI, F. I. et al. Mensuração e análise de custos de transação arcados por produtores de leite nos mercados formal e informal da Região de São Carlos, SP. Organizações Rurais \&
Agroindustriais, v.10, n.3, p.343-358, 2008. Avialable from: $<$ http://revista.dae.ufla.br/index.php/ora/article/view/70>. Accessed: Mar, 21, 2020.

BARROSO, L. P.; ARTES, R. Análise Multivariada. 1. ed. Lavras : Universidade Federal de Lavras, 2003.

BONDENMÜLLER FILHO, A.; BÁNKUTI, F. I. Dinâmica do processo decisional e fluxo adaptativo de sistemas de produção leiteiros. In: PAULUS, D.; PARIS, W. Técnicas de manejo agropecuário sustentável. Curitiba : UTFPR Editora, 2016, p.326.

BONDENMÜLLER FILHO, A. et al. Typology of production systems based on milk characteristics.Revista Brasileira de Zootecnia, v.39, n.8, p.1832-1839, 2010. Available from: <https://www.rbz.org.br/wp-content/uploads/articles $\mathrm{xml} / 1516-3598-\mathrm{rbz}-\mathrm{S} 1516-35982010000800028 / 1516-3598-$ rbz-S1516-35982010000800028.pdf>. Accessed: Dec. 14, 2019. doi: $10.1590 / \mathrm{S} 1516-35982010000800028$.

BOZO, G. A. et al.Adequacy of somatic cell count and total bacterial count in refrigerated raw milk to the parameters of the legislation. Arquivo Brasileiro de Medicina Veterinária e Zootecnia, v.65, n.2, p.589-594, 2013. Available from: <http:// dx.doi.org/10.1590/S0102-09352013000200040>. Accessed: Jan. 19, 2020. doi: 10.1590/S0102-09352013000200040.

BRASIL. Lei n.11326, de 24 de julho de 2006. Estabelece as diretrizes para a formulação da Política Nacional da Agricultura Familiar e Empreendimentos Familiares Rurais. Available from: <http:// www.planalto.gov.br/ccivil 03/ Ato2004-2006/2006/Lei/L11326. htm\#: :text=LEI\%20N\% $2 \%$ BA $\% 2011.326 \% 2 \mathrm{C} \% 20 \mathrm{DE} \% 20$ $24 \% 20 \mathrm{DE} \% 20 \mathrm{JULHO} \% 20 \mathrm{DE} \% 202006 . \&$ text=Estabelece $\% 20$ as\%20diretrizes\%20para\%20a,Art.>. Accessed: Apr. 04, 2020.

BRITO, M. M. de. et al. Horizontal arrangements: strategy for reducing the asymmetry information for dairy farmers in Paraná, Brazil. Ciência Rural, v.45, n.11, p.2069-2075, 2015a. Available from: <https://doi.org/10.1590/0103-8478cr20141724>. Accessed: May, 30, 2020. doi: 10.1590/0103-8478cr20141724.

BRITO,M.M.de.etal.Horizontalarrangementsand competitiveness of small-scale dairy farmers in Paraná, Brazil. International Food \& Agribusiness Management Review, v.18, n.4, p.155-172, 2015b. Available from: <https://pdfs.semanticscholar.org/9daa/ e14a01cc63d1095fe746e3c71cee39cd1288.pdf>. Accessed: May, 29, 2020. doi: 10.22004/ag.econ.211658.

BUAINAIN, A. M. et al. Sete teses sobre o mundo rural brasileiro. Revista de Política Agrícola, v.22, n.2, p.1-25, 2013. Available from: $<$ https://seer.sede.embrapa.br/index.php/RPA/article/view/311>. Accessed: May, 29, 2020.

BUAINAIN, A. M. et al. Agricultura Familiar e Tecnologia no Brasil: características, desafios e obstáculos. Campinas : Editora da Unicamp, 2007. 1v, p.238.

BYRNE, T. J. et al. Analyzing the heterogeneity of farmers' preferences for improvements in dairy cow traits using farmer typologies. Journal of Dairy Science, v.98, n.6, p.4148-4161, 2015. Available from: <https://doi.org/10.3168/jds.2014-9194>. Accessed: May, 22, 2020. doi: 10.3168/jds.2014-9194.

CASALI, M. et al. Information asymmetry among dairy producers in Paraná, Brazil. Semina: Ciências Agrárias, v.41, n.1, p.293304, 2020. Available from: <http://dx.doi.org/10.5433/1679- 
0359.2020v41n1p295>. Accessed: Mar. 27, 2020. doi: $10.5433 / 1679-0359.2020 \mathrm{v} 41 \mathrm{n} 1 \mathrm{p} 295$.

CHIKOWO, R. et al. Farm typologies, soil fertility variability and nutrient management in smallholder farming in Sub-Saharan Africa. Nutrient Cycling in Agroecosystems, v.100, p.1-18, 2014. Available from: <https://doi.org/10.1007/s10705-014-9632-y>. Accessed: May, 25, 2020. doi: 10.1007/s10705-014-9632-y.

CONWAY, S. F. et al. Uncovering obstacles: The exercise of symbolic power in the complex arena of intergenerational family farm transfer. Journal of Rural Studies, v.54, p.60-75, 2017. Available from: <https://doi.org/10.1016/j.jrurstud.2017.06.007>. Accessed: May, 22, 2020. doi: 10.1016/j.jrurstud.2017.06.007.

CORTEZ-ARRIOLA, J. et al. Leverages for on-farm innovation from farm typologies? An illustration for family-based dairy farms in north-west Michoacán, Mexico. Agricultural Systems, v.135, p.66-76, 2015. Available from: <https://doi.org/10.1016/j. agsy.2014.12.005>. Accessed: Jun. 01, 2020. doi: 10.1016/j. agsy.2014.12.005.

DEFANTE, L. et al. Typology of dairy production systems that meet Brazilian standards for milk quality, Revista Brasileira de Zootecnia, 49, p.2009-2016, 2019. Available from: <http:// www.scielo.br/pdf/rbz/v48/1806-9290-rbz-48-e20180023.pdf>. Accessed: Jun. 01, 2020. doi: 10.1590/rbz4820180023.

ECKSTEIN, I. I. et al. Qualidade do leite e sua correlação com técnicas de manejo de ordenha. Scientia Agraria Paranaensis, v.13, n.2, p.143-151, 2014. Available from: <http://dx.doi. org/10.18188/sap.v13i2.7071>. Accessed: May, 29, 2020. doi: 10.18188/sap.v13i2.7071.

ECKSTEIN, I. I. et al. Typification of Factors Related to Milk Production and Its Impact on the Sanitary Quality of Milk. Scientia Agraria Paranaensis, v.15, n.1, p.56-63, 2016. Available from: <http://dx.doi.org/10.18188/sap.v15i1.10589>. Accessed: Apr. 23, 2020. doi: 10.18188/sap.v15i1.10589.

EMBRAPA - EMPRESA BASILEIRA DE PESQUISA AGROPECUÁRIA. Medidas de eficiência da atividade leiteira: índices zootéenicos para rebanhos leiteiros. Comunicado Técnico n. 54, 2007. Available from: <https://ainfo.cnptia. embrapa.br/digital/bitstream/item/65441/1/COT-54-Medidas-deeficiencia.pdf>. Accessed: Mar. 24, 2019.

FAO - FOOD AND AGRICULTURE ORGANIZATION OF THE UNITED NATIONS. Livestock primary. 2018. Available from: $<$ http://www.fao.org/faostat/es/\#data/QL $>$. Accessed: Apr. 2, 2020.

FÁVERO, L. P. et al. Análise de dados: Modelagem multivariada para tomada de decisões. Rio de Janeiro : Elsevier, 2009a.

FÁVERO, L.P. et al. Análise de dados: Modelagem multivariada para tomada de decisões. Rio de Janeiro : Elsevier, 2009b. 2v.

FIELD, A. Descobrindo a estatística usando o SPSS. Porto Alegre : Artmed, 2009. 2v.

HAIR, J.F.J. et al. Multivariate Data Analysis. Saddle River : Prentice Hall, 2009. 7v.

IBGE - INSTITUTO BRASILEIRO DE GEOGRAFIA E ESTATÍTICA. Censo Agropecuário 2006. Available from: $<$ https://sidra.ibge.gov.br/pesquisa/censo-agropecuario/censo- agropecuario-2006/dados-sobre-agricultura-familiar-fao-incra $>$. Accessed: Aug. 12, 2018.

IBGE. Censo Agropecuário, 2017a. Available from: <http:// ibge.gov.br/estadosat/temas.php?sigla $=$ go\&tema $=$ censoagro $>$. Accessed: Aug. 23, 2017.

IBGE. Censo Agropecuário, 2017b. Available from: <https:// censos.ibge.gov.br/agro/2017>. Accessed: Aug. 23, 2017.

IBGE. Estimativas de População - 2019. Available from: $<$ https://sidra.ibge.gov.br/pesquisa/estimapop/tabelas $>$. Accessed: Nov. 10, 2018.

LANGE, M. J. et al. Typology of dairy production systems based on the characteristics of management in the Region of West Paraná. Semina: Ciências Agrárias, v.37, n.1, p.473, 2016. Available from: <http://www.uel.br/revistas/uel/index.php/ semagrarias/article/viewFile/21221/18018>. Accessed: May, 30, 2020. doi: 10.5433/1679-0359.2016v37n1p473.

MARION FILHO, P.J.; REICHERT, H. Mudanças institucionais recentes na produção de leite brasileira: IN 51 versus IN 62. Revista de Administração e Negócios da Amazônia, v.6, n.2, p.75-88, 2014. Available from: <https://doi.org/10.18361/2176-8366/rara. v6n2p75-88>. Accessed: May, 22, 2020. doi: 10.18361/2176-8366/ rara.v6n2p75-88.

MAPA - MINISTÉRIO AGRICULTURA, PECUÁRIA E ABASTECIMENTO. Instrução Normativa n. 51, de 18 de setembro de 2002. Available from: $<$ http://adcon.rn.gov.br/acervo/ emater/doc/doc000000000001051.pdf $>$. Accessed: Apr. 02, 2020.

MAPA. Instrução Normativa n. 62, de 29 de dezembro de 2011. Available from: <http://www.universidadedoleite.com.br/ imagens/uploads/files/instru??o_normativa_62.pdf $>$. Accessed: Apr. 02, 2020.

MAPA. Instrução Normativa n. 31, de 29 de junho de 2018. Diário Oficial da União, 2018a, Edição 125, Seção 1, p. 2. Available from: $<$ http://www.in.gov.br/materia/-/asset_publisher/Kujrw0TZC2Mb/ content/id/28166433/do1-2018-07-02-instrucao-normativa-n-31de-29-de-junho-de-2018-28166402>. Accessed: May, 15, 2020.

MAPA. Instrução Normativa n. 76, de 26 de novembro de 2018. Diário Oficial da União, 2018b, Edição 230, Seção 1, p. 10. Available from: <http://www.in.gov.br/materia/-/asset_publisher/ Kujrw0TZC2Mb/content/id/52750137/do1-2018-11-30-instrucaonormativa-n-76-de-26-de-novembro-de-2018-52749894IN\%20 76>. Accessed: Apr. 13, 2020.

MAPA. Instrução Normativa n. 77, de 26 de novembro de 2018. Diário Oficial da União, 2018c, Edição 230, Seção 1, p. 10. Available from: <http://www.in.gov.br/materia/-/asset_publisher/ Kujrw0TZC2Mb/content/id/52750141/do1-2018-11-30-instrucaonormativa-n-77-de-26-de-novembro-de-2018-52749887>. Accessed: May, 27, 2020.

MARCONDES, M. I. et al. Impact of farm size on milk quality in the Brazilian dairy industry according to the seasons of the year. Ciência Rural, v.47, n.11, 2017. Available from: <https://doi. org/10.1590/0103-8478cr20161004>. Accessed: Apr. 25, 2020. doi: $10.1590 / 0103-8478 \mathrm{cr} 20161004$.

MARTÍNEZ-GARCÍA, C. G. et al. Factors influencing adoption of improved grassland management by small-scale dairy farmers 
in central Mexico and the implications for future research on smallholder adoption in developing countries. Livestock Science, v.152, n.2-3, p.228-238, 2013. Available from: <https://doi. org/10.1016/j.livsci.2012.10.007>. Accessed: Jun. 4, 2020. doi: 10.1016/j.livsci.2012.10.007.

MEDINA, G. et al. Development conditions for family farming: Lessons from Brazil. World Development, v.74, p.386-396, 2015. Available from: $<$ https://doi.org/10.1016/j.worlddev.2015.05.023 $>$. Accessed: Jun. 4, 2020. doi: 10.1016/j.worlddev.2015.05.023.

NEUMANN, M.E. et al. Typology of dairy production systems from West Parana State based on production indices and feed used. Semina: Ciencias Agrarias, v.37, n.3, p.1565-1580, 2016. Available from: <http://dx.doi.org/10.5433/16790359.2016v37n3p1565>. Accessed: Jun. 4, 2020. doi: $10.5433 / 1679-0359.2016 \mathrm{v} 37 \mathrm{n} 3 \mathrm{p} 1565$.

QUDDUS, M. Adoption of dairy farming technologies by small farm holders: practices and constraints. Bangladesh Journal of Animal Science, v.41, n.2, p.124-135, 2012. Available from: $<$ https://doi.org/10.3329/bjas.v41i2.14132>. Accessed: Jun. 3, 2020. doi: $10.3329 /$ bjas.v41i2.14132.

SCHEBELESKI, P. G.; BÁNKUTI, S. M. S. Estratégias de cooperação e competição no sistema agroindustrial do leite no paraná: Um estudo no segmento produtor. Revista Perspectivas Contemporâneas, v.11, n.1, p.165-187, 2016. Available from: <http://revista2 grupointegrado.br/revista/index.php/perspectivascontemporaneas/ article/view/1960>. Accessed: Jun. 2, 2020.

SILVA, S. A. S. D de. et al. Microbiological quality of raw milk and effect on quality by implementing good management practices, Procedia Food Science, vol.6, p.92-96, 2016. Available from: $<$ https://doi.org/10.1016/j.profoo.2016.02.019>. Accessed: Jun. 3, 2020. doi: 10.1016/j.profoo.2016.02.019.
SOUZA, R. P. de; BUAINAIN, A. M. A competitividade da produção de leite da agricultura familiar: os limites da exclusão. Estudos Sociedade e Agricultura, v.21, n.2, p.308-331, 2013. Available from: <https://revistaesa.com/ojs/index.php/esa/article/ view/370>. Accessed: Apr. 26, 2020.

SURANINDYAH, Y. et al. The effect of improving sanitation prior to milking on milk quality of dairy cow in farmer group. Procedia Food Science, v.3, p.150-155, 2015. Available from: $<$ https://doi. org/10.1016/j.profoo.2015.01.016>. Accessed: Jun. 1, 2020. doi: 10.1016/j.profoo.2015.01.016.

VOGES, J. G. et al. Milk quality and its relationship with the production system and structure for milking. Revista Brasileira de Ciência Veterinária, v.22, n.3-4, p.171-175, 2015. Available from: <http://dx.doi.org/10.4322/rbcv.2016.009>. Accessed: May, 25, 2020. doi: 10.4322/rbcv.2016.009

YABE, M. T. et al. Characteristics of milk production systems and feed strategies for dairy cows in the North and Northwest of Paraná State. Semina: Ciências Agrárias, v., n.6, p.44694480, 2015. Available from: <http://dx.doi.org/10.5433/16790359.2015v36n6Supl2p4469>. Accessed: Jun. 2, 2020. doi: 10.5433/1679-0359.2015v36n6Supl2p4469.

ZIMPEL, R. et al. Characteristics of the dairy farmers who perform financial management in Paraná State, Brazil. Revista Brasileira de Zootecnia, v.46, n.5, p.421-428, 2017. Available from: <https:// doi.org/10.1590/s1806-92902017000500008>. Accessed: Jan. 31, 2020. doi: 10.1590/s1806-92902017000500008.

ZYMPEL, R. et al. Socioproductive Characterization of Milk Production Systems. Scientia Agraria Paranaensis, v.15, n.3, p.283-290, 2016. Available from: <http://dx.doi. org/10.18188/1983-1471/sap.v15n3p283-290>. Accessed: Jan. 30, 2020. doi: 10.18188/1983-1471/sap.v15n3p283-290. 